\title{
HUBUNGAN SELF ESTEEM DENGAN ORIENTASI MASA DEPAN SISWA
}

\author{
Siti Aisyah \\ Elok Halimatus Sakdiyah \\ Fakultas Psikologi, \\ Universitas Islam Negeri Maulana Malik Ibrahim Malang,
}

\begin{abstract}
Abstrak - Penelitian ini bertujuan untuk mengetahui korelasi antara self esteem dengan orientasi masa depan siswa. Metode penelitian yang digunakan adalah metode penelitian kuantitatif dengan teknik pengambilan sampel purposive sampling. Pengambilan data menggunakan dua skala, yaitu skala self esteem dan skala orientasi masa depan. Metode analisis utama yang digunakan adalah analisis product moment dan uji t untuk mengetahui perbedaan berdasar jenis kelamin. Berdasarkan hasil penelitian, didapatkan hasil bahwa self esteem berkorelasi positif terhadap orientasi masa depan siswa dengan nilai korelasi $r=0.496, p=0.01$. Self liking ditemukan menjadi aspek pembentuk utama dari self esteem, dan motivasi merupakan aspek pembentuk utama dari orientasi masa depan. Self competence menjadi kontributor utama pada motivasi. Self esteem dan orientasi masa depan laki-laki ditemukan sedikit lebih tinggi dibanding perempuan.
\end{abstract}

\section{Keyword : Self Esteem, Orientasi masa Depan}

PSIKOISLAMIKA. Jurnal Psikologi Islam (JPI) copyright @ 2015 Pusat Penelitan dan Layanan Psikologi. Volume 12. Nomor 2, Tahun 2015

\section{PENDAHULUAN}

Masa remaja adalah masa yang sangat tepat untuk membangun masa depan. Di usia remaja, individu masih mempunyai langkah panjang untuk menjangkau semua yang diharapkan. Kegagalan membangun masa depan pada masa remaja akan berakibat negatif dalam mengarungi masa dewasanya serta dapat berimbas pada masa depan remaja tersebut. Rencana masa depan dalam konsep psikologi dikenal dengan orientasi masa depan (OMD). Orientasi masa depan mencakup hal-hal yang berkaitan dengan aspek pendidikan, dunia kerja serta hidup berumah tangga (Desmita, 2013: 199). Seniger, menjelaskan bahwa orientasi masa depan erat kaitannya dengan penetapan, perencanaan dan pengambilan keputusan dalam hidup seseorang untuk masa depannya (Putri: 2010).

Masa remaja adalah sebuah masa yang dimana terdapat tuntutan untuk mulai memikirkan masa depannya secara serius (Desmita, 2013:199). Ginzberg menyatakan bahwa ketika remaja memasuki usia
17-18 tahun hingga awal usia 20-an pilihan terhadap karir akan semakin realistis (Santrock, 2003: 484). Remaja akan ditempatkan pada pilihan-pilihan dan minat-minat, baik minat pada pendidikan dan juga pekerjaan (Hurlock, 1980: 220). Akan tetapi seringkali pengambilang keputusan terhadap pendidikan maupun karir yang dibuat para siswa mengalami hal yang menyulitkan dan tidak terduga (Santrock, 2003:485). Beberapa siswa cenderung merasa kebingungan menentukan pilihan jurusan saat memasuki perguruan tinggi atau kebingungan dalam menentukan jenis pekerjaan yang akan digeluti jika tidak melanjutkan pendidikan di perguruan tinggi.

Jika kemampuan seseorang menjadi tolak ukur sebuah kesuksesan, maka individu seharusnya mengenal dan menghargai kemampuan dirinya. Mengenali dan menghargai kemampuan diri merupakan bagian penting dari self esteem. Menurut Tafarodi \& Swaan (2001) kemampuan diri (self compentence) merupakan salah satu aspek dari self esteem. Beberapa penelitian di negara 
Eropa membuktikan bahwa self esteem berkorelasi positif dengan peningkatan keberhasilan pada diri siswa. Self esteem yang dimiliki individu berperan dalam mempengaruhi orientasi masa depan mereka di masa mendatang (Rokayah: 2011).

Pengaruh self esteem terhadap orientasi masa depan juga telah banyak didokumentasikan dalam beberapa penelitian Indonesia. Jika hasil penelitian terdahulu lebih banyak dilakukan pada mahasiswa, maka dalam penelitian ini peneliti tertarik mengujinya pada siswa SMA kelas XI berfokus pada orientasi masa depan bidang karir, ditinjau dari perbedaan jenis kelamin. Beberapa penelitian membuktikan, meski tidak selalu konsisten, tingkat self esteem berbeda berdasarkan jenis kelamin. Penelitian Ancok, dkk (daam Ghufron dan Risnawati, 2011) membuktikan wanita seringkali memiliki perasaan kurang mampu, dan hal tersebut peneliti asumsikan akan mempengaruhi tingkat orientasi masa depan mereka. Self esteem merupakan keyakinan diri terhadap potensi dan kemampuan yang dimiliki oleh seorang individu, sedangkan orientasi masa depan bidang karir pada individu, membutuhkan keyakinan terhadap kemampuan dalam menentukan tujuan yang jelas untuk masa depan yang lebih baik dan terarah.

\section{KERANGKA KERJA TEORITIK}

\section{Self Esteem}

Rosenberg (Tafarodi dan Swann, 1995) mengatakan bahwa self esteem adalah evaluasi keseluruhan seorang individu sebagai seorang manusia, yang dikonseptualisasikan sebagai konstruk yang bersifat undimensional. Selanjutnya, Tafarodi \& Swann (2001) menambahkan dua aspek dalam self esteem yakni self competence (kompetensi diri) dan self liking (menyukai diri atau penerimaan diri). Self competence dan self liking memiliki pengaruh penting bagi perkembangan individu. Tafarodi \& Milne; Tafarodi \& Swann (2001) menjelaskan bahwa self competence dan self liking ini bersifat timbal balik, artinya, individu yang merasa berharga akan menilai dirinya sebagai orang yang mampu, dan individu yang merasa tidak berharga akan menilai dirinya sebagai orang yang tidak mampu.

Ghufron \& Risnawita (2011: 45-46) menyatakan bahwa harga diri (self esteem) terbentuk dari hasil interaksi individu dengan lingkungan berdasarkan penghargaan, penerimaan, dan pengertian orang lain terhadap dirinya. Terdapat beberapa faktor yang dapat memengaruhi self esteem salah satunya yaitu faktor jenis kelamin. Menurut Ancok dkk wanita seringkali merasa self esteemnya lebih rendah dari pada pria, seperti merasa kurang mampu, merasa kurang percaya diri, atau merasa harus dilindungi. Peran orang tua dan harapan-harapan masyarakat yang berbeda-beda baik pada pria maupun pada wanita ditengarai menjadi sebab dari rendahnya kepercayaan diri wanita.

Orientasi Masa Depan dan Aspek-Aspeknya

Desmita (2013: 199) menjelaskan bahwa orientasi masa depan merupakan salah satu fenomena perkembangan kognitif yang terjadi pada individu yang berada pada masa remaja. Nurmi (1991: 1) berpendapat bahwa orientasi masa depan adalah gambaran utama dari cara berfikir dan bertindak seseorang mengenai peristiwa dimasa mendatang beserta hasilnya. Atas dasar tersebut Nurmi menggambarkan orientasi masa depan ke dalam tiga proses psikologis, yaitu motivasi, perencanaan dan juga evaluasi. Ketiga proses itu secara runtut terjadi ketika seseorang membentuk sebuah orientasi masa depan dalam dirinya. Tahap motivasi merupakan tahap awal pembentukan orientasi masa depan remaja. Tahap ini mencangkup motif, minat dan tujuan berkaitan dengan orientasi masa depan. Aspek perencanaan merupakan tahap kedua dari proses pembentukan orientasi masa depan individu, yaitu bagaimana remaja membuat perencanaan tentang perwujudan minat dan tujuan mereka agar dapat terealisasikan (Nurmi, 1991: 2). Evaluasi merupakan aspek ketiga dan tahap akhir dari proses pembentukan orientasi masa depan. Dalam tahap ini remaja harus mengevaluasi terealisasinya tujuan dan rencana yang telah mereka dibentuk dan ditetapkan (Nurmi: 1).

Berk berpendapat bahwa terdapat beberapa faktor yang dapat memengaruhi dan menentuhan dalam pemilihan karir seorang remaja, diantaranya adalah faktor orang tua, gender, karakteristik diri dan juga faktor teman sebaya (peer group) (Daryo, 2004: 67). Masyarakat seringkali menilai seseorang berdasarkan peran jenis kelamin. Masih banyak dijumpai masyarakat yang menghendaki jenis pekerjaan tertentu dilakukan oleh jenis kelamin tertentu pula. Artinya, jenis kelamin menentukan seseorang dalam memilih karir pekerjaan. Kebanyakan perempuan akan mengambil tanggung jawab karir yang dianggapnya tidak banyak mengganggu peran jenis gendernya, misalnya seperti dosen/guru, dokter, sekertaris, penjaga toko, psikolog anak dan sebagainya. Demikian pula sebaliknya seorang lakilaki akan memilih jenis karir yang sesuai dengan peran jenis gendernya, misalnya tentara, polisi, hakim/jaksa dan sebagainya (Daryo: 2004: 67). 


\section{METODE PENELITIAN}

\section{Subjek Penelitian}

Penelitian dilakukan pada remaja siswa SMAN 3 di kota Malang, berjumlah 140 siswa. Subjek penelitian diambil dengan menggunakan teknik teknik purposive sampling dengan kriteria sebagai berikut:

1. Siswa SMA kelas XI

2. Berusia 16-18 tahun

3. Telah menerima pelajaran bimbingan karir.

\section{Definisi oprasional Variabel}

Definisi oprasional Variabel dari kedua variabel yakni sebagai berikut:

1. Self esteem (Varibel Independen)

Mengacu pada pendapat Tafarodi \& Swann, self esteem didefinisikan sebagai evaluasi diri yang dilakukan individu terhadap dirinya sendiri secara global, mengandung dua aspek yaitu self competence (kompetensi diri) dan self liking (menyukai diri atau penerimaan diri)

2. Orientasi Masa Depan (Variabel Dependen)

Mengacu pada pendapat Nurmi, orientasi masa depan adalah proses perencanaan, pemikiran, harapan, peraturan, strategi ataupun gambaran yang dibuat seseorang terhadap pandangannya ke masa depan khususnya bidang karir, mengandung . tiga aspek, yaitu motivasi, perencanaan, dan evaluasi.

\section{Alat Ukur}

Dalam penelitian ini, alat ukur yang digunakan adalah:

1. Skala self esteem. Skala self esteem di adaptasi dari skala Tafarodi \& Swann (2001) dan skala self esteem dari Rosenberg (1965), berjumlah 20 aitem

2. Skala orientasi masa depan di adaptasi dari skala Laurence Steinberg, dkk (2009: 43), dengan jumlah 52 aitem.

Kedua skala tersebut di uji validitas isi dengan menggunakan Aiken's $V$ dan validitas konstruk dengan metode Rasch Model. Kemudian data yang diperoleh dianalisis dengan menggunakan korelasi Product Moment.

\section{HASIL}

Dari hasil analisis data dapat diketahui bahwa tingkat masing-masing variabel dan juga masingmasing aspek dalam variabel sebagai berikut:
Tabel 1. Katagorisasi Keseluruhan Variabel dan Aspek

\begin{tabular}{clcc}
\hline Variabel dan Aspek & Katagori & $\mathrm{F}$ & $\%$ \\
\hline Self Esteem & Sedang & 76 & 54,3 \\
\hline Self Competence & Sedang & 78 & 55,7 \\
\hline Self Liking & Tinggi & 74 & 52,9 \\
\hline Orientasi Masa Depan & Tinggi & 76 & 54,3 \\
\hline Motivasi & Sedang & 71 & 50,7 \\
\hline Perencanaan & Sedang & 110 & 78,6 \\
\hline Evaluasi & Tinggi & 85 & 60,7 \\
\hline
\end{tabular}

Selanjutnya, setelah dilakukan uji korelasi antar kedua variabel, terbukti bahwa hipotesis penelitian diterima, yang berarti bahwa ada hubungan positif signifikan antara self esteem dengan orientasi masa depan pada siswa SMA kelas XI di SMA Negeri 3 Malang. Hal ini berarti penilaian remaja yang positif terhadap diri dan kemampuan yang dimiliki berperan penting dalam proses pembentukan orientasi masa depannya. Aspek-aspek yang membentuk orientasi masa depan yakni motivasi, perencanaan dan evaluasi lebih dipengaruhi oleh seberapa baik evaluasi dan penilaian remaja dirinya sendiri .

Marcia (Jackman, 2012: 47) menjelaskan bahwa harga diri yang tinggi pada remaja dapat membantu pengembangan idintitas remaja. Teori mengenai self menyatakan bahwa remaja yang berfikir kritis mengenai masa depan mereka serta memiliki pandangan positif dan memiliki semangat yang lebih tinggi dalam mengeksplorasi berbagai aspek identitas dirinya, dibandingkan remaja yang tidak berfikir kritis mengenai masa depan (Jackman: 2012). $\mathrm{Hal}$ ini berarti secara tidak langsung self esteem dengan orientasi masa depan memiliki hubungan yang saling menguatkan. Dalam penelitiannya Jackman (2012:47) mengatakan bahwa meskipun belum ada acuan yang jelas, namun dari berbagai penelitian dijelaskan mengenai proses self esteem dengan orientasi masa depan remaja berkembang secara bersamaan.

Tabel 2. Uji Korelasi Self Esteem dengan Orientasi Masa Depan

\begin{tabular}{|c|c|c|c|}
\hline & & SelfEsteem & OMD \\
\hline \multirow{3}{*}{ SelfEsteem } & $\begin{array}{l}\text { P e a r s o n } \\
\text { Correlation }\end{array}$ & 1 & $.496 "$ \\
\hline & Sig. (1-tailed) & & .000 \\
\hline & $\mathrm{N}$ & 140 & 140 \\
\hline \multirow{3}{*}{ OMD } & $\begin{array}{l}\text { P e a r s o n } \\
\text { Correlation }\end{array}$ & $.496^{\circ}$ & 1 \\
\hline & Sig. (1-tailed) & .000 & \\
\hline & $\mathrm{N}$ & 140 & 140 \\
\hline
\end{tabular}


Berdasarkan kontribusi aspek pada masingmasing variabel, menunjukkan bahwa aspek self liking merupakan aspek pembentuk utama pada variabel self esteem dibanding aspek self competence. Menurut Damon \& Hart, Popper \& Eccles (Tafarodi dan Swann, 1995), penilaian ini menginternalisasi kemampuan individu untuk memandang dan menilai dirinya sebagai individu sosial yang berkembang. Self liking merupakan acuan bagi remaja untuk dapat menghargai dirinya sendiri dengan cara menerima dirinya atas dasar penilaian yang diberikan orang lain.

Selanjutnya, aspek pembentuk utama orientasi masa depan adalah aspek motivasi. Hasil ini, dapat dimengerti karena tahap motivasi merupakan tahap awal pembentukan orientasi masa depan remaja. $\mathrm{Hal}$ ini sesuai dengan karakteristik masa remaja, yang mulai dituntutan untuk memikirkan masa depannya secara serius. Dalam proses pembentukan orientasi masa depan, tahapan motivasi mencangkup motif, minat dan tujuan remaja yang berkaitan dengan orientasi masa depannya (Desmita, 2013). Menurut Nurmi (1991) tahapan motivasi ini merupakan proses yang kompleks, yang melibatkan beberapa subtahap seperti pengetahuan mengenai harapan terhadap masa depan, ketertarikan mengenai tujuan di masa depan, mengeksplorasi pengetahuan mengenai masa depannya, menetapkan tujuan dan juga memiliki komitmen pada tujuan masa depan yang telah dipilinnya.

Berdasarkan korelasi peraspek dari self esteem terhadap aspek-aspek dari orientasi masa depan ditemukan bahwa self competence memberikan kontiribusi paling tinggi pada aspek motivasi sebagai pembentuk utama orientasi masa depan. Hal ini berarti penilaian remaja atas kemampuan dan kompetensi dirinya akan meningkatkan motif, minat dan tujuan remaja yang berkaitan dengan orientasi masa depannya.

Tabel 3. Uji Korelasi Aspek Self Esteem dengan Aspek Orientasi Masa Depan

\begin{tabular}{llllllll}
\hline \multicolumn{1}{c}{$\begin{array}{c}\text { Peason } \\
\text { Correlation }\end{array}$} & \multicolumn{1}{c}{$\begin{array}{c}\text { Self } \\
\text { Esteem }\end{array}$} & $\begin{array}{c}\text { Self } \\
\text { Competence }\end{array}$ & \multicolumn{1}{c}{$\begin{array}{c}\text { Self } \\
\text { Liking }\end{array}$} & \multicolumn{2}{c}{$\begin{array}{c}\text { Orientasi } \\
\text { Masa Depan }\end{array}$} & \multicolumn{2}{c}{ Motivasi Perencanaan Evaluasi } \\
\hline Self Esteem & 1 & 0,847 & 0,903 & 0,496 & 0.415 & 0.346 & 0.655 \\
\hline Self Competence & 0.847 & 1 & 0.536 & 0.530 & 0.431 & 0.386 & 0.707 \\
& & & & & & & \\
\hline Self Liking & 0.903 & 0.536 & 1 & 0.358 & 0.310 & 0.238 & 0.467 \\
\hline $\begin{array}{l}\text { Orientasi Masa } \\
\text { Depan }\end{array}$ & 0.496 & 0.530 & 0.358 & 1 & 0.946 & 0.865 & 0.806 \\
\hline Motivasi & 0.415 & 0.431 & 0.310 & 0.946 & 1 & 0.703 & 0.673 \\
\hline Perencanaan & 0.346 & 0.386 & 0.238 & 0.865 & 0.703 & 1 & 0.609 \\
\hline Evaluasi & 0.655 & 0.707 & 0.467 & 0.806 & 0.673 & 0.609 & 1 \\
\hline
\end{tabular}

Berdasarkan uji beda variable berdasar jenis kelamin didapatkan hasil bahwa tingkat self esteem dan orientasi masa depan pada siswa laki-laki sedikit lebih tinggi dibandingkan siswa perempuan. Hasil ini mempertegas hasil-hasil penelitian sebelumnya yang memperoleh hasil yang sama.

Tabel 4. Uji Beda Jenis Kelamin Tingkas Self Esteem dan Orientasi Masa Depan

\begin{tabular}{lllll}
\multirow{2}{*}{ Variabel } & \multicolumn{2}{l}{ Jumlah Responden } & \multicolumn{2}{c}{ Mean } \\
\cline { 2 - 5 } & $\begin{array}{l}\text { Laki- } \\
\text { Laki }\end{array}$ & Perempuan & $\begin{array}{l}\text { Laki- } \\
\text { Laki }\end{array}$ & Perempuan \\
\hline Self Esteem & 57 & 83 & 44.09 & 42.88 \\
\hline $\begin{array}{l}\text { Orientasi } \\
\text { Masa Depan }\end{array}$ & 83 & 144.98 & 141.24 \\
\hline
\end{tabular}

\section{KESIMPULAN}

1. Tingkat variabel self esteem berada pada katagori sedang dengan prosentasi $54,3 \%$. a. Self liking merupakan aspek pembentuk utama self esteem yang memiliki kontribusi lebih tinggi dibanding self competence.

b. Tingkat self esteem pada siswa lakilaki sedikit lebih tinggi dibanding siswa perempuan.

2. Tingkat orientasi masa depan mayoritas remaja berada pada kategori tinggi dengan prosentase $54,3 \%$.

a. Aspek motivasi merupakan aspek pembentuk utama dari orientasi masa depan remaja.

b. Tingkat orientasi masa depan pada siswa laki-laki sedikit lebih tinggi dibandingkan dengan siswa perempuan.

3. Terdapat hubungan positif dan signifikan antara self esteem dengan orientasi masa depan pada siswa SMA kelas XI di SMA Negeri 3 Malang. 
4. Aspek dari self esteem yang memberikan kontiribusi paling tinggi pada aspek pembentuk

\section{DAFTAR PUSTAKA}

Desmita. (2013). Psikologi Perkembangan. Bandung: PT Remaja Rosdakarya.

Putri, A.S. (2010). Cinta dan Orientasi Masa Depan Hubungan Romantis Pada Dewasa Muda yang Berpacaran.(Skripsi). Fakultas Psikologi Program Strata 1 Reguler Universitas Indonesia, Jakarta.

Nurmi, J.E. (1991). How Do Adolencents See Their Future? A Review of the Development of Future Orientation and Planning. Development Review.

Hudarta, J.S. \& Kusnaedi, N. (2010). Pertumbuhan dan Perkembangan Peserta Didik (Olahraga dan kesehatan). Bandung: Penerbit Alfabeta.

Hurlock, E.B. (1980). Psikologi Perkembangan: Suatu Pendekatan Sepanjang Rentang Kehidupa, (5nd ed). Jakarta: Penerbit Erlangga.

Tafarodi, R.W. \& Swann Jr, W.B. (2001). Two-Dimensional Self Esteem: Theory and Measurement: Personality and Individual Differences, Departemnt of psychology, University of Toronto \& Department of Psychology, University of Texas at Austin, 653-673. utama orientasi masa depan adalah aspek self competence.
Murk, C.J. (2006). Self-Esteem Research, Theory, and Practice. New York: Springer Publishing Company, Inc.

Rokayah, S. (2011). Hubungan Self- Esteem Anak Jalanan Dengan Orientasi Masa Depan Dalam Bidang Pernikahan. (Skripsi). Jurusan Psikologi Universitas Pendidikan Indonesia.

Rosenberg. (1965). Rosenberg Self-Esteem Scale. Sugiyono. (2011). Metode Penelitian Kuantitatif Kualitatif $R \& D$. Bandung: Penerbit Alfabeta.

Steinberg, L. (2009). Age Differences In Future Orientation and Discaunting: Child Development, Vol.80, Number 1, Pages 28-44.

Gufron, M. \& Risnawita S. (2011). Teori-teori Psikologi. Yogyakarta: Ar-Ruzz Media.

Wijaya, F. Hubungan antara Kematangan Karir dengan Motivasi Belajar pada Siswa Kelas X MAN Cibinong. Universitas Gunadarma.

Santrock, J.W. (2003). Adolescence Perkembangan: Remaja Edisi ke Enam. Jakarta: Penerbit Erlangga. 